\title{
Workshopy k menšinové otázce v Budapešti a Kolíně spoluorganizované PFUK
}

Právnická fakulta - hlavně Ústav právních dějin - se nadále intenzívně věnuje právnímu postavení menšin. Koncem února 2019 se uskutečnily v budově fakulty hned tři poměrně velké akce k právním otázkám menšin a migrací, v květnu šlo o dva menší workshopy v Budapešti a Kolíně. V Budapešti dne 3. května 2019 se jednalo o akci Ústavu právních věd Společensko-výzkumného centra Mad'arské akademie věd, do které se zapojila PFUK, s názvem „Výzkumné ústavy pre menšiny v strednej Európe včera a dnes“. V Kolíně PFUK s Regionálním muzeem Kolín zorganizovaly dne 21. května 2019 malou konferenci - workshop „Menšiny, turismus a právo“. Př́spěvky z workshopů budou základem publikace Halász, I. - Petráš, R. a kol. Menšiny, výzkumné ústavy a právo, respektive Petráš a kol. Menšiny, turismus a právo, které vydá nakladatelství Auditorium v rámci řady, kde již vyšla kniha Halász, I. - Petráš, R. a kol. Menšiny, vysoké školy a právo, a dokončuje se Kuklík, J. - Petráš, R. a kol. Menšiny, sport a právo.

V ubytovacím zařízení Mad'arské akademie věd na Hradě v Budapešti se dne 3. května uskutečnil pracovní workshop ke středoevropským výzkumným centrům věnujícím se menšinám. Na úvod hovořil prof. Iván Halász z Mad'arské akademie věd, dlouhodobě spolupracující s PFUK i přímo s Právněhistorickými studiemi, o cílech akce a možnostech výzkumu, na což navázal dr. René Petráš (PFUK). Prof. Jan Kuklík (děkan PFUK) se kvůli zdravotním důvodům oproti svým původním plánům nemohl akce účastnit.

Dr. Ondřej Kolář ze Slezského zemského muzea hovořil o svém pracovišti, kterým je Slezský ústav - dřive mnohaletá základna výzkumu menšin v českých zemích začleněná jako ústav v Akademii věd, v současnosti fungující v rámci Slezského zemského muzea. Zájem o menšiny zde byl bohužel zásadně oslaben a posílilo se zaměření na regionální historii. Prof. Štefan Šutaj nastínil vývoj druhého hlavního menšinového výzkumného ústavu v Československu, který naštěstí funguje dodnes, tedy Spoločenskovedného ústavu v Košicích, jehož byl ostatně řadu let ředitelem. Doc. Attila Simon hovořil o méně známém, poměrně novém ústavu Fórum inštitút pre výskum menšín v Šamoríne. Doc. László Szarka referoval o Ústavu pro menšiny Mad'arské akademie věd (Kisebbségkutató Intézet MTA), který dokonce zakládal. Dr. René Petráš (PFUK) nastínil vývoj výzkumů právního postavení menšin v ČR a možnosti institucionalizace takovýchto aktivit. Poslední referát přednesl doc. Wladyslaw Peksa z Krakowa o situaci v Polsku, kde takováto na menšiny specializovaná výzkumná centra nejsou. Poté následovala rozsáhlá diskuse o plánovaných výzkumech a předpokládané knize - kolektivní monografii. 
V nově zrekonstruované budově Regionálního muzea Kolín dne 21. května na úvod workshopu „Menšiny, turismus a právo“ po pozdravu ředitele muzea Mgr. Vladimíra Rišlinka hovořil dr. René Petráš (PFUK) o cílech akce, tedy hlavně o problémech menšinových památek a jejich využití pro turismus. Doc. Jiří Vaníček z Vysoké školy ekonomické se věnoval kulturnímu - a to hlavně náboženskému - cestovnímu ruchu v ČR. Starosta Kolína Mgr. Vít Rakušan pozdravil účastníky a hovořil o praktických problémech využívání památek. Doc. Blanka Soukupová z Fakulty humanitních studií UK se věnovala postoji státu a židovské reprezentace po druhé světové válce $\mathrm{k}$ židovským památkám a jejich turistickému využití. Plánován byl i referát děkana PFUK prof. Jana Kuklíka k problémům restitucí menšinového - zejména židovského - majetku a jeho využití pro turismus.

Doc. Jan Štemberk z Vysoké školy obchodní nastínil mnohé otázky menšin a turismu v české historii. Stejně jako mnozí další účastníci obou akcí je právním historikem dlouhodobě spolupracujícím s Právněhistorickými studiemi a výrazně se podílel zejména na speciálním čísle 48/1 věnovaném historii turismu. Dr. Ondřej Kolář ze Slezského zemského muzea hovořil o situaci hrobů a pomníků hlavně německé menšiny, což je již několik let téma, které zabírá nejvíce času Radě vlády pro národnostní menšiny. S posledním referátem o problémech památkové ochrany synagog v Rakousku a ČR vystoupil prof. Wolfgang Wieshaider (Universität Wien, Juridikum), odborník na náboženské právo. Po workshopu následovala prohlídka židovské čtvrti Kolína včetně odborné diskuse, kde přednášeli dr. Miroslava Jouzová z Městské knihovny Kolín a dr. Ladislav Jouza z Regionálního muzea v Kolíně.

René Petráš

doi: $10.14712 / 2464689 X .2019 .45$ 